\title{
The importance of qualified care of nursing in hanseniasis and neuropathies
}

\author{
Souza Leão, B. M. L 1; Câmara, N. S. 2; Vasconcelos, J. L. A. ${ }^{3}$
}

${ }^{1}$ Student of the Nursing Course; ${ }^{2}$ Student of the Nursing Course, ${ }^{3} \mathrm{PhD}$ in Therapeutic Innovation / Docent of Nursing and Biomedicine undergraduate courses - ${ }^{1,2},{ }^{3}$ ASCES/UNITA

\begin{abstract}
Introduction: Leprosy is a chronic infectious disease caused by the bacillus Mycobacterium leprae, popularly known as leprosy, and has great neuropathic potential, as it affects the nervous system, causing severe sequelae. It mainly affects low-income people, who live in places without basic sanitation and without adequate housing conditions. Because it is a secular disease and with immense prejudice, people who are affected seek health networks late because of fear, causing delay in diagnosis and bringing severe sequelae to them, and may even be irreversible. Objective: To understand leprosy and its neuropathic potential, emphasizing the importance of nursing a qualification. Methodology: This is a literature review, whose data collection was performed through the SciELO and Lilacs databases. A total of 8 conventional and non-conventional articles were found, using the descriptors leprosy, nursing, basic health unit and early diagnosis. Results and Discussion: In all forms of leprosy, there is a nervous compromise occurring a preference for the sensory-autonomic nerves of the dermis and in the region of the nerve trunk becoming a standard feature of the disease, so people tend to develop deficiency and physical deformities, But its impact will depend on the immunity of the individual. The nurse of the unit, properly trained becomes essential in the monitoring and healing process of the patient. Conclusion: It is of fundamental importance that nursing qualify to serve these users, so that in the future, they will not suffer from severe neuropathic sequelae, hindering their daily activities, their social experiences and self esteem.
\end{abstract}

Keywords: Basic health Unit; Diagnosis; Leprosy; Nursing

*Correspondence to Author:

Souza Leão, B. M. L

ASCES/UNITA

How to cite this article:

Souza Leão, B. M. L ; Câmara, N. S. ; Vasconcelos, J. L. A.The importance of qualified care of nursing in hanseniasis and neuropathies. International Journal of Pain Research and Treatment, 2018, 1:4

\section{eScîPub}

eSciPub LLC, Houston, TX USA.

Website: http://escipub.com/ 